\title{
Role of Different Cover Crops on DTPA-Extractable Micronutrients in an Apricot Orchard
}

\begin{abstract}
Zeynep Demir ${ }^{1, a, *}$, Nihat Tursun ${ }^{2, b}$, Doğan Işı $k^{3, c}$
${ }^{1}$ Soil, Fertilizer and Water Resources Central Research Institute, 06172 Ankara, Turkey

${ }^{2}$ Department of Plant Protection, Faculty of Agriculture, Inonu University, 44000 Malatya, Turkey

${ }^{3}$ Department of Plant Protection, Erciyes University, Faculty of Agriculture, 38280 Kayseri, Turkey *Corresponding author

\section{A R T I C L E I N F O}

Research Article

Received : 11/07/2018

Accepted : 24/04/2019

\section{Keywords:}

Cover crops

DTPA-extractable micronutrients Soil pH

Clay texture

Apricot orchard

\section{A B S T R A C T}

This study was conducted to compare the effect of different cover crop treatments on DTPAextractable micronutrients $(\mathrm{Fe}, \mathrm{Mn}, \mathrm{Zn}, \mathrm{Cu})$ and soil $\mathrm{pH}$ in an apricot orchard with clay texture located in Malatya province of Turkey. For this purpose, 5 different experimental groups (Vicia villosa Roth (VV), Vicia pannonica Crantz (VP), Vicia pannonica Crantz and Tritikale mixture $(70 \%+30 \%$, respectively) (VPT), Phacelia tanacetifolia Benth (PT), Fagopyrum esculentum Moench (FE)) and 3 control groups (mechanically cultivated (MC), herbicide treatment (HC) and bare control plot (BC)) were used in the apricot orchards. The soils were sampled from $0-20 \mathrm{~cm}$ and $20-40 \mathrm{~cm}$ depths in each plot for soil analyses. According to the obtained results, while cover crop treatments reduced $\mathrm{pH}$ values of soils according to the bare control, the cover crops increased the $\mathrm{Fe}, \mathrm{Mn}$ and $\mathrm{Zn}$ contents of soils in the $0-20 \mathrm{~cm}$ soil depth. The highest Ext-Fe, Mn and $\mathrm{Zn}$ contents were obtained in the VV (14.83 $\mathrm{mg} \mathrm{kg}^{-1}, 8.42 \mathrm{mg} \mathrm{kg}^{-1}, 1.03 \mathrm{mg} \mathrm{kg}^{-1}$, respectively) at the $0-20 \mathrm{~cm}$ soil depth. As compared to bare control, highest percent increases in Fe, Mn and $\mathrm{Zn}$ contents were determined in the VV $27.73 \%, 31.69 \%$ and $37.54 \%$, respectively. The greatest significant negative correlations in the VV treatment were observed between $\mathrm{pH}$ and $\mathrm{Fe}\left(-0.985^{* *}\right)$, between $\mathrm{pH}$ and $\mathrm{Mn}$ $\left(-0.945^{* *}\right)$ and between $\mathrm{pH}$ and $\mathrm{Zn}(-0.764 *)$. The greatest significant negative correlations in the VP treatment were observed between $\mathrm{pH}$ and $\mathrm{Fe}\left(-0.948^{* *}\right)$, between $\mathrm{pH}$ and $\mathrm{Mn}\left(-0.928^{* *}\right)$ and between $\mathrm{pH}$ and $\mathrm{Zn}(-0.722 *)$. It was concluded based on current findings that cover crops, especially Vicia villosa Roth and Vicia pannonica Crantz could be incorporated into cropping systems to improve micronutrients and to provide a sustainable soil management.
\end{abstract}

Türk Tarım - Gıda Bilim ve Teknoloji Dergisi 7(5): 698-706, 2019

\section{Kayısı Bahçesinde DTPA ile Ekstrakte Edilebilir Mikroelementler Üzerine Farklı Örtücü Bitkilerin Rolü}

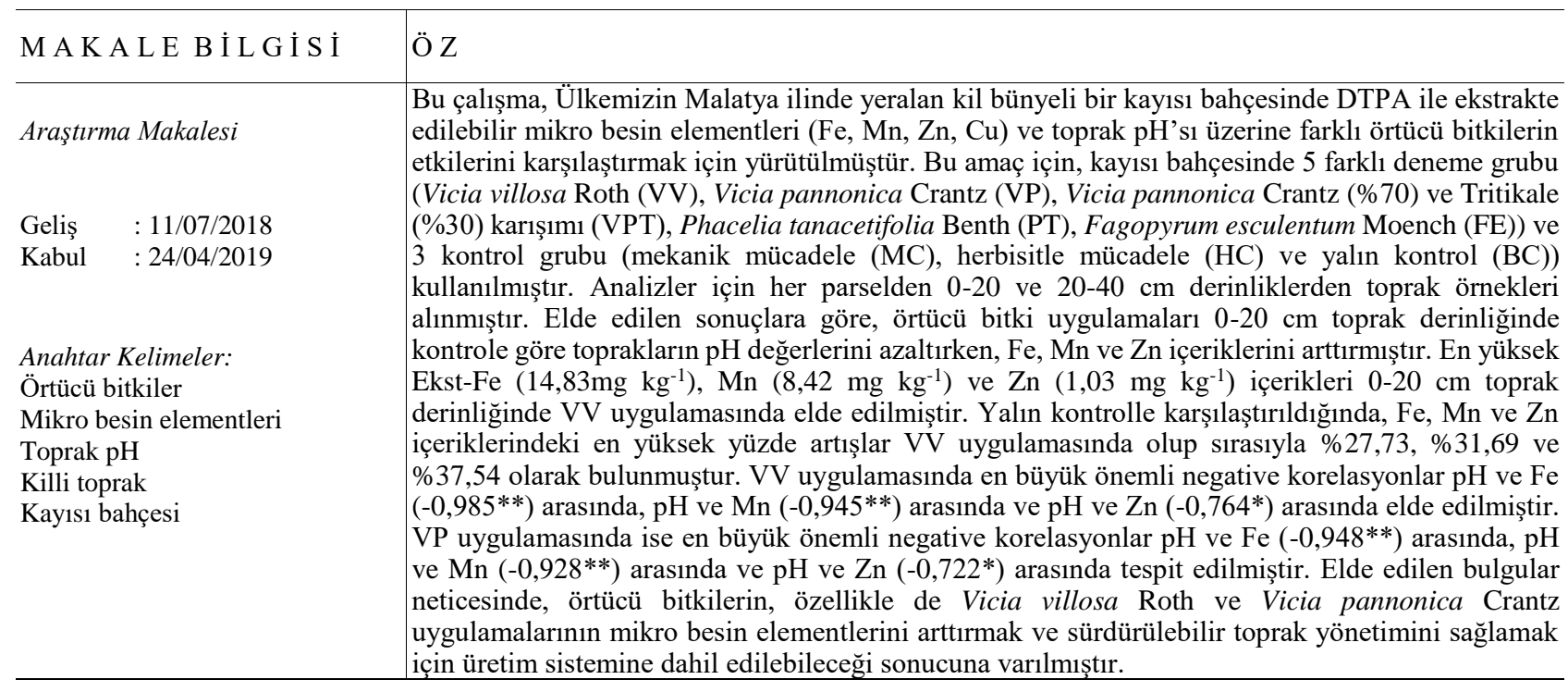




\section{Introduction}

Soil micronutrients play a major role to maintain soil health (Singh, 2012). Determining soil variability and maintaining soil health is very much important for ecological modelling, environmental predictions, precise agriculture and management of natural resources (Wang, 2009). Proportionate to primary and secondary nutrients, plants need a much smaller quantity of micronutrients. However, their importance is still great. Besides, these nutrients increase root growth which is related to nutrient and water absorption by crop plants and thus improving yields (Ibrahım and Faryal, 2014). Demir et al. (2019) determined that cover crop treatments (Vicia pannonica Crantz, Vicia pannonica Crantz (70\%) + Tritikale (30\%) mixture, Phacelia tanacetifolia Benth., Vicia villosa Roth., and Fagopyrum esculentum Moench.) increased fruit weight in an apricot orchard with clay soil. A shortage of micronutrients can limit plant growth and crop yields. Too great a shortage could even because plant death, even with all other essential elements fully represented (Singh, 2012). Micronutrient deficiencies occur not only because of insufficient quantities present in soil, but also can happen due to low solubility, which can be affected by soil organic matter, adsorptive surface, soil $\mathrm{pH}$, nutrient interactions, and texture (Ayele et al., 2013). These nutrients availability is commonly regulated by several soil attributes (White and Broadley, 2009). For instance, changes in $\mathrm{pH}$ and soil redox potential are the most significant features that could affect these nutrient availability (Brady and Weil, 2014). Soil $\mathrm{pH}$ can impact plant growth based on its influence on the availability of essential plant nutrients (Brady and Weil, 2002). Similarly, soil organic matter and its decomposition processes have a important and direct effect on the availability of these nutrients (Marschner and Rengel, 2007). Other factors like antagonist and synergistic interactions among these nutrients and necessity elements could also generally affect these nutrient uptakes by crops (Fageira, 2002).

One of the main problems in recent years is lack of the micronutrients in different areas of the World (Brady and Weil, 1999). Using nitrogen fertilizers increases the vegetative period and causes lack of $\mathrm{Mn}, \mathrm{Fe}, \mathrm{Zn}$ and $\mathrm{Cu}$ in soil (Loneragan and Webb, 1993). They are also reported to cause long-term adverse effects, while bio-based products are more likely to dissolve easily and thus not pollute the environment (Ying, 2006). Besides, these costly practices is not environmentally sustainable since it carries a strict risk of nitrate contamination of water and soil ( $\mathrm{Ju}$ et al., 2006). The inappropriate and intensive use of soil for agricultural production decreases soil fertility and aggravates the degradation of soil organic matter. The application of cover crops that supply plant residues support to sustain and even increment soil organic matter and enhances soil fertility (Carvalho et al., 2011). Cover crops with big root systems may uptake nutrients from deep soil profiles and after chemical desiccation, during straw deterioration, release the nutrients in the soil surface (Pacheco et al., 2011). The use of cover crops typically supplies for increments in organic matter contents through the years (Nascente et al., 2013). Cover crops subscribed to increased research on distinct maintain soil management strategies (Lal, 2009). Thus, new approaches should be evaluated for sustainable human health, soil management and environmental protection. While there are many studies on cover crops, studies dealing with effects on DTPA-extractable micronutrients of the Vicia villosa Roth (VV), Vicia pannonica Crantz (VP), Vicia pannonica Crantz and Tritikale mixture $(70 \%+30 \%$, respectively) (VPT), Phacelia tanacetifolia Benth (PT), Fagopyrum esculentum Moench (FE) in apricot orchard are very limited. The micronutrient $(\mathrm{Cu}, \mathrm{Fe}, \mathrm{Mn}$ and $\mathrm{Zn})$ use efficiency varied from cover crop to cover crop as well as from nutrient to nutrient. Cover crop species varied in nutrient use efficiency with change in P levels. Fageria et al. (2015) determined that the micronutrient use efficiency was in the order of $\mathrm{Cu}>\mathrm{Zn}>\mathrm{Mn}>\mathrm{Fe}$. Higher $\mathrm{Cu}$ use efficiency was associated with lower uptake of this element, in the cover crop tops compared to other micronutrients. Similarly, lower efficiency of Fe and $\mathrm{Mn}$ was associated with their higher uptake in the tops of cover crops. $\mathrm{Cu}, \mathrm{Mn}$ and $\mathrm{Zn}$ use efficiency decreased with increasing $\mathrm{P}$ levels, whereas Fe efficiency increased with the addition of $\mathrm{P}$ in the growth medium (Fageria et al., 2015). The aims of this study were: i) to compare the effect of different cover crop treatments on DTPA-extractable micronutrients $(\mathrm{Fe}, \mathrm{Mn}, \mathrm{Zn}$ and $\mathrm{Cu})$ and soil $\mathrm{pH}$ in an apricot orchard with clay texture soil, ii) to identify relationship between soil $\mathrm{pH}$ and DTPA-extractable Fe, $\mathrm{Mn}, \mathrm{Zn}$ and $\mathrm{Cu}$.

\section{Material and Methods}

Experiment was conducted in the experimental apricot orchard at Inonu University in 2015 and 2016. Experimental site is located at $38.47 \mathrm{~N}-38.34 \mathrm{E}$, had an average temperature of $13.4^{\circ} \mathrm{C}$ in 2015 - 2016 growing season, and mean annual precipitation of $420 \mathrm{~mm}$.

The cover crop treatments consisted of Vicia villosa Roth (VV), Vicia pannonica Crantz (VP), Vicia pannonica Crantz and Tritikale mixture $(70 \%+30 \%$, respectively) (VPT), Phacelia tanacetifolia Benth (PT), Fagopyrum esculentum Moench (FE). Vicia villosa Roth, Vicia pannonica Crantz, a mixture of Vicia pannonica Crantz and triticale (70\% Vicia pannonica Crantz), Phacelia tanacetifolia Benth were used as winter cover crops and Fagopyrum esculentum Moench was used summer cover crop. Fagopyrum esculentum, which is a concealment plant for the summer, were planted in the years 21.04.2014 and 05.05.2015 and the other winter covering plants were planted in the fall periods of the years 23.10.2014 and 23.10.2015.

The results of the experiment were taken in 2015 and 2016 for summer and winter covered plants. The field experiment was done using randomized complete blocks design with four replications. Cover crops were grown on the same plot. Experiment included control plots [bare control (BC), herbicide control (HC) and mechanical control (MC)]. Soil samples were collected from two depths $(0-20,20-40 \mathrm{~cm})$ in each plot.

Each soil sample was separately air-dried, ground and passed through a $2 \mathrm{~mm}$ sieve prior to determining the DTPA-extractable micronutrients (Fe, $\mathrm{Mn}, \mathrm{Zn}$ and $\mathrm{Cu}$ ) and soil $\mathrm{pH}$. Soil particle size distribution was determined with hydrometer method (Demiralay, 1993); soil $\mathrm{pH}$ values were determined from 1:1 (v:v) soil - water suspension with a $\mathrm{pH}$ meter; soil electrical conductivity $\left(\mathrm{EC}_{25^{\circ} \mathrm{C}}\right)$ was determined from the same soil-water suspension with an 
EC meter (Kacar, 1994); exchangeable cations were determined with ammonia acetate extraction (Kacar, 1994); and micronutrients by the extraction with DTPA extraction solution by using atomic absorption spectrophotometers according to Kacar (1994). Modified Walkley-Black method was employed to determine organic matter (OM) contents of soil samples (Kacar, 1994). Initial soil characteristics are provided in Table 1. Initial analyses revealed that experimental soils were clay in texture, slightly alkaline with low organic matter contents (Soil Survey Staff, 1993).

Experimental results were subjected to statistical analyses with SPSS Version 16.0 statistic software package. Data were subjected to ANOVA. Treatment means were compared with Duncan's multiple range test at the 0.01 probability level and correlation analyses were performed to express the relationships between experimental parameters. In the evaluation of the 2015 and 2016 data were performed independent two samples t-test analysis (Yurtsever, 1984).

\section{Results and Discussion}

The DTPA-extractable micronutrients (Fe, Mn and $\mathrm{Zn}$ ) and soil $\mathrm{pH}$ values were significantly influenced by the cover crop treatments at $0-20 \mathrm{~cm}$ soil depth. While cover crop treatments in the apricot orchard with clay texture soil importantly decreased $\mathrm{pH}$ values of soils according to the bare control, the cover crop treatments increased the DTPA-extractable micronutrients (Fe, Mn and $\mathrm{Zn}$ ) of soils in the $0-20 \mathrm{~cm}$ soil depth. Higher improvement rates were generally observed in the second year of the experiments (2016). In both years of the experiment, important differences were generally not observed in the DTPAextractable micronutrients (Fe, $\mathrm{Mn}$ and $\mathrm{Zn}$ ) and $\mathrm{pH}$ values of a plot mechanically cultivated, herbicide treatment and bare control in the orchard.
$\mathrm{pH}$ of the soils generally declined with cover crops treatments according to the bare control in the apricot $\operatorname{orchard}(\mathrm{F}=21.715, \mathrm{P}=0.000)$ (Figure 1).

Extractable Fe contents of the soils generally increased with cover crops treatments according to the bare control in the apricot orchard $(\mathrm{F}=57.892, \mathrm{P}=0.000)$ (Figure 2a). The highest extractable Fe content $\left(14.83 \mathrm{mg} \mathrm{kg}^{-1}\right)$ in the second year of the experiment was obtained in the VV treatment while the lowest extractable Fe content (11.13 $\mathrm{mg} \mathrm{kg}^{-1}$ ) was in the HC treatment at $0-20 \mathrm{~cm}$ soil depth. Extractable Fe contents $\left(\mathrm{mg} \mathrm{kg}^{-1}\right)$ was ordered as; $\mathrm{HC}$ $(11.13)<\mathrm{MC}(11.21)<\mathrm{BC}(11.61)<\mathrm{FE}(13.29)<\mathrm{PT}$ $(13.33)<$ VPT $(13.61)<\mathrm{VP}(14.45)<\mathrm{VV}(14.83)$. As compared to bare control, percent increases in extractable Fe content at $0-20 \mathrm{~cm}$ soil depth varied between $14.47 \%$ in FRR and $27.73 \%$ in $\mathrm{VV}$ treatments $(\mathrm{F}=57.892, \mathrm{P}=$ 0.000) (Figure 3b). The extractable Fe contents under cover crops were higher than the beginning values. Vicia villosa Roth and Vicia pannonica Crantz, due to their big and depth root systems, have larger ability to mobilize nutrients from deep soil profiles to the topsoil. The identified results is consistent with the result attained by Sharma et al. (2003), Mathur et al. (2006), Yadav (2011), Yadav and Meena (2009) and Sidhu and Sharma (2010). Franzluebbers and Hons (1996) also determined raises in micronutrients in soil under cover crop treatments. Similarly, by increase on $\mathrm{pH}$, available iron decreases progressively and vice-versa. Yadav (2011) who suggested that the reduced $\mathrm{Fe}$-availability with increasing $\mathrm{pH}$ might be attributed to the conversion of $\mathrm{Fe}^{2+}$ to $\mathrm{Fe}^{3+}$ ions. The ferric ion $\left(\mathrm{Fe}^{3+}\right)$ compounds have low solubility in solution and so are less bio-available (Landon, 1984). Cover crops increment the contents of micronutrients in the soil and decrease the application of fertilizers, causing to lower costs of production and suppling to the maintainability (Bernardi et al., 2003). From these conclusions, it could be deduced that there is a large significance of using cover crops to cycle micronutrients.

Table 1 Soil physico-chemical characteristics at the beginning of experiment

\begin{tabular}{|c|c|c|c|c|c|}
\hline \multirow{2}{*}{ Soil properties } & \multicolumn{2}{|c|}{ Dept, cm } & \multirow{2}{*}{ Soil properties } & \multicolumn{2}{|c|}{ Dept, cm } \\
\hline & $0-20 \mathrm{~cm}$ & $20-40 \mathrm{~cm}$ & & $0-20 \mathrm{~cm}$ & $20-40 \mathrm{~cm}$ \\
\hline Sand, $\%$ & 19.75 & 20.28 & OM, \% & 1.73 & 0.87 \\
\hline Silt, \% & 28.38 & 27.20 & $\mathrm{Ca}$, meq $100 \mathrm{~g}^{-1}$ & 18.26 & 18.01 \\
\hline Clay, \% & 51.88 & 52.58 & $\mathrm{Mg}$, meq $100 \mathrm{~g}^{-1}$ & 5.78 & 5.69 \\
\hline $\mathrm{pH}(1: 1)$ & 7.43 & 7.44 & $\mathrm{Na}$, meq $100 \mathrm{~g}^{-1}$ & 0.37 & 0.41 \\
\hline $\mathrm{EC}_{25^{\circ} \mathrm{C}}, \mathrm{ds} / \mathrm{m}$ & 0.661 & 0.657 & $\mathrm{~K}$, meq $100 \mathrm{~g}^{-1}$ & 1.03 & 0.76 \\
\hline
\end{tabular}

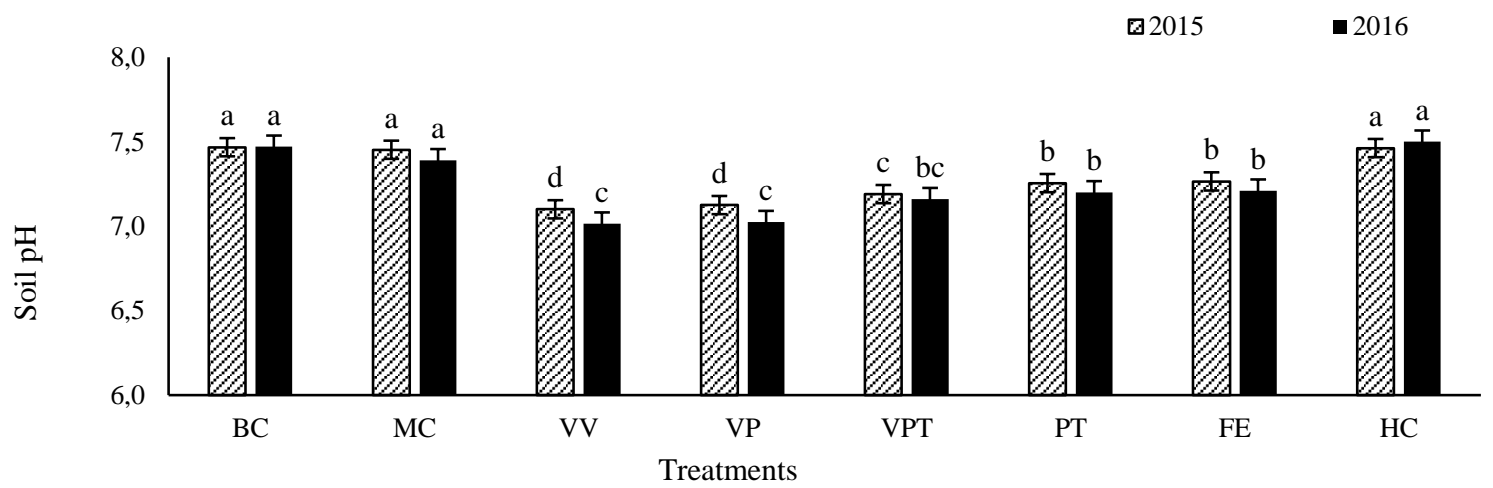

Figure 1 Effects of cover crops and other treatments on soil $\mathrm{pH}$ at $0-20 \mathrm{~cm}$ soil depth in the apricot orchard 
$\mathbf{a}$

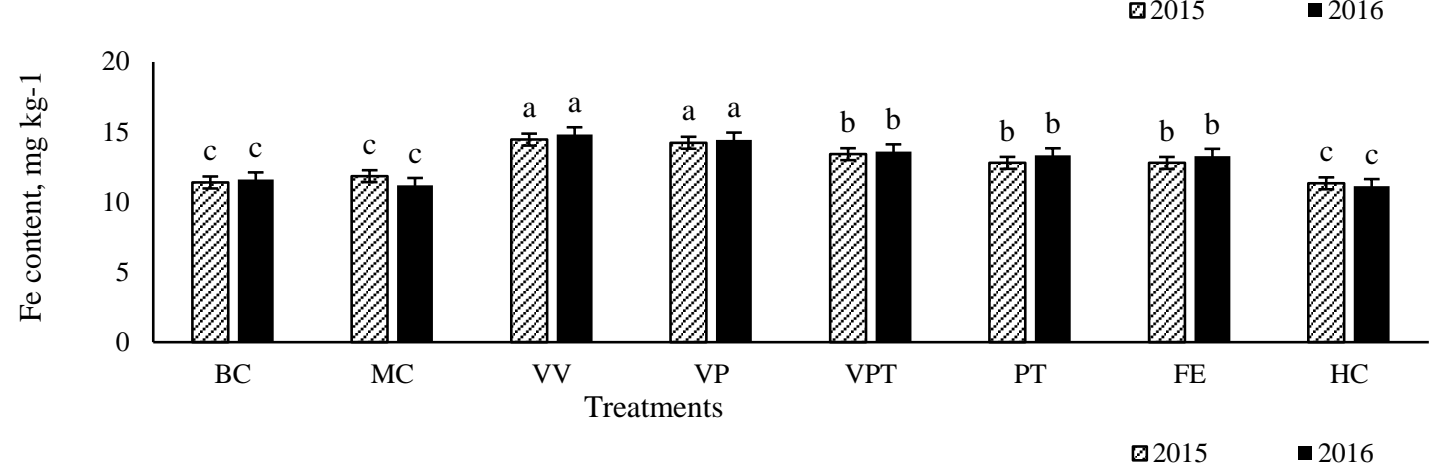

b

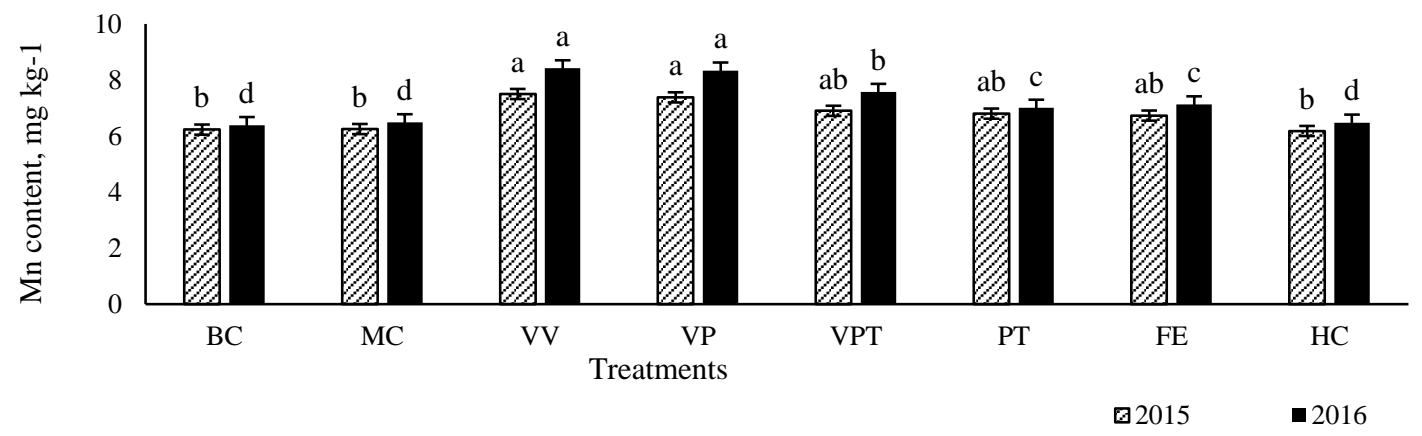

c

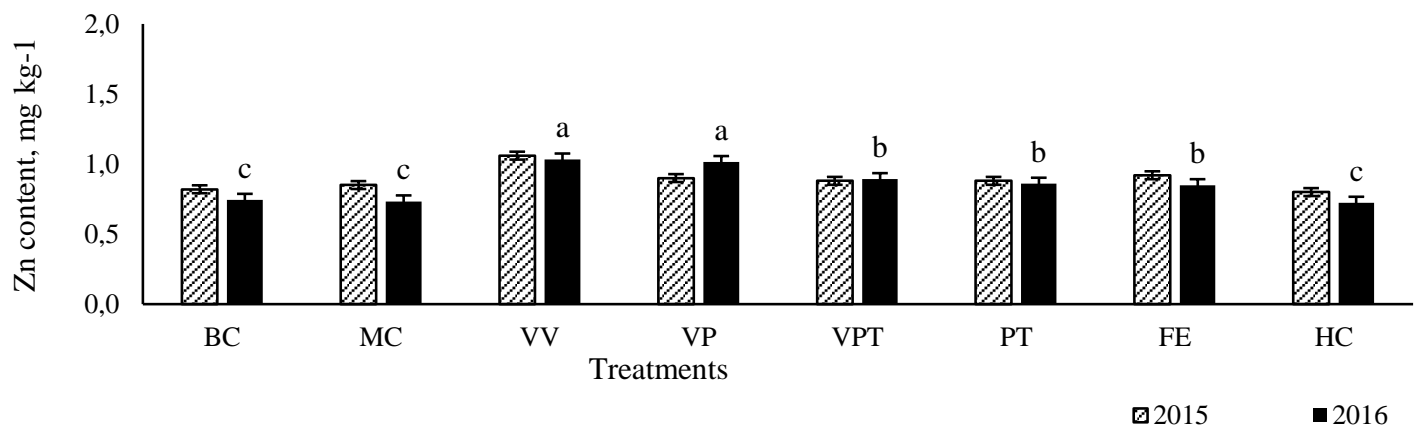

d

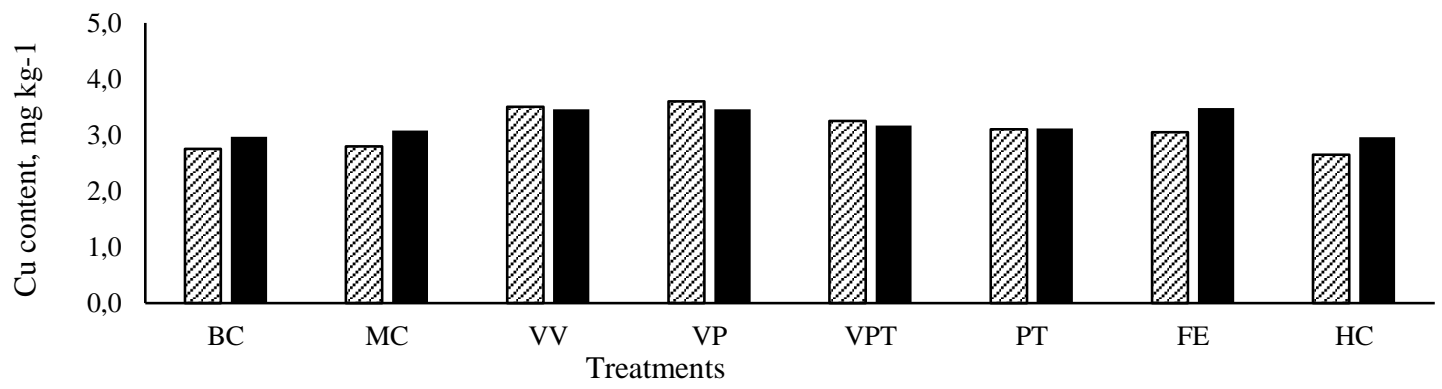

Figure 2 Effects of cover crops and other treatments on a) $\mathrm{Fe}$, b) $\mathrm{Mn}, \mathrm{c}$ ) $\mathrm{Zn}$ and d) $\mathrm{Cu}$ at $0-20 \mathrm{~cm}$ soil depth in the apricot orchard

The cover crop treatments in the second year of the experiment decreased soil $\mathrm{pH}$ from 7.500 in the $\mathrm{HC}$ treatment to 7.015 in VV treatment at $0-20 \mathrm{~cm}$ soil depth. Soil $\mathrm{pH}$ was ordered as; VV $(7.015)<\mathrm{VP}(7.024)<$ VPT $(7.160)<\mathrm{PT}(7.200)<\mathrm{FE}(7.210)<\mathrm{MC}(7.390)<\mathrm{BC}$ (7.470) < $\mathrm{HC}$ (7.500). As compared to bare control, percent decreases in soil $\mathrm{pH}$ values at $0-20 \mathrm{~cm}$ soil depth varied between $3.48 \%$ in FE and $6.09 \%$ in VV treatments orchard $(\mathrm{F}=21.715, \mathrm{P}=0.000)$ (Figure 3a). Nutrient availability is highly correlated with soil $\mathrm{pH}$. At high soil $\mathrm{pH}, \mathrm{Fe}, \mathrm{Mn}, \mathrm{Cu}$ and $\mathrm{Zn}$ may be deficient for plant growth (Brady and Weil, 2002). Increasing or decreasing the range of soil $\mathrm{pH}$ affects the micronutrient availability to plants and is considered to be a great factor for nutrient deficiency. Soil $\mathrm{pH}$ and the properties of the organic matter in the soil are important soil properties which affect the nutrient availability. In this study, cover crops used as organic matter importantly influenced the soil $\mathrm{pH}$ orchard $(\mathrm{F}=21.715, \mathrm{P}=0.000)$. The crops have exudation of acids to the soil from their roots that could play directly on the soil pH (Moreti et al., 2007). According to Fabian (2009) the soil prefers nutrient accumulation at the surface, raised organic matter contents and decrease in soil $\mathrm{pH}$. When soil organic matter is also mineralized there is produce of organic acids that could help to incremented soil acidity (Garcia and Rosolem, 2010). In this study, soil $\mathrm{pH}$ under cover crops were different and lower than the beginning values. This can be due to the removal of bases by the plants grown in this orchard. 
Extractable Mn contents of the soils generally increased with cover crops treatments according to the bare control in the apricot orchard orchard $(\mathrm{F}=59.006, \mathrm{P}=$ 0.000) (Figure 2b). The highest extractable Mn content $\left(8.42 \mathrm{mg} \mathrm{kg}^{-1}\right)$ in the second year of the experiment was obtained in the VV treatment while the lowest extractable Mn content (6.39 $\left.\mathrm{mg} \mathrm{kg}^{-1}\right)$ was in the BC treatment at 0-20 $\mathrm{cm}$ soil depth. Extractable $\mathrm{Mn}$ contents $\left(\mathrm{mg} \mathrm{kg}^{-1}\right)$ was ordered as; $\mathrm{BC}(6.39)<\mathrm{HC}(6.48)<\mathrm{MC}(6.49)<\mathrm{PT}(7.01)$ $<$ FE $(7.13)<\operatorname{VPT}(7.57)<\mathrm{VP}(8.34)<\mathrm{VV}(8.42)$. As compared to bare control, percent increases in extractable Mn content at $0-20 \mathrm{~cm}$ soil depth varied between $9.69 \%$ in PT and $31.69 \%$ in VV treatments $(\mathrm{F}=59.006, \mathrm{P}=0.000)$ (Figure 3c). Similar result was also determined by Sharma et al. (2003), Mathur et al. (2006), Yadav (2011), Yadav and Meena (2009) and Sidhu and Sharma (2010). In this study, cover crop treatments caused notable changes of available Mn. The increase might be due to decline in soil reaction and improved dissolution of Mn compounds. Application of organic fertilizer to soils increases available $\mathrm{Mn}$ concentration ( $\mathrm{Li}$ et al. 2009). Decreasing $\mathrm{pH}$, available manganese increases gradually and vice-versa. $\mathrm{Mn}^{2+}$ concentration in soil solution should theoretically reduce 100 -fold for every unit of soil $\mathrm{pH}$ raise (Barber, 1995). With increasing soil $\mathrm{pH}, \mathrm{Mn}^{2+}$ is converted into its higher oxides $\left(\mathrm{Mn}^{4+}\right.$ and $\left.\mathrm{Mn}^{3+}\right)$ which are insoluble in water might be the reason for decreasing concentration of available Mn with increasing soil $\mathrm{pH}$.

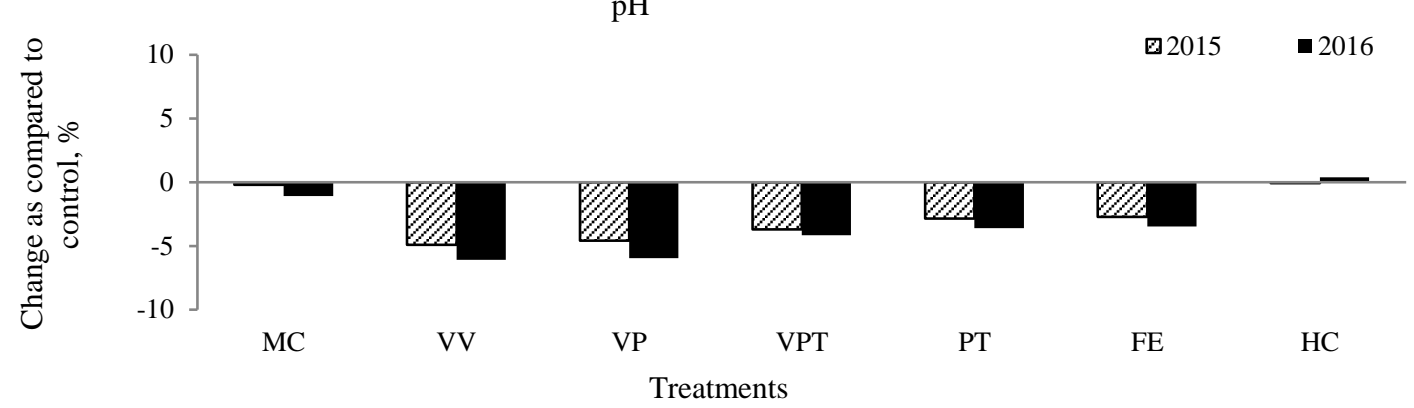

b

$\mathrm{Fe}$

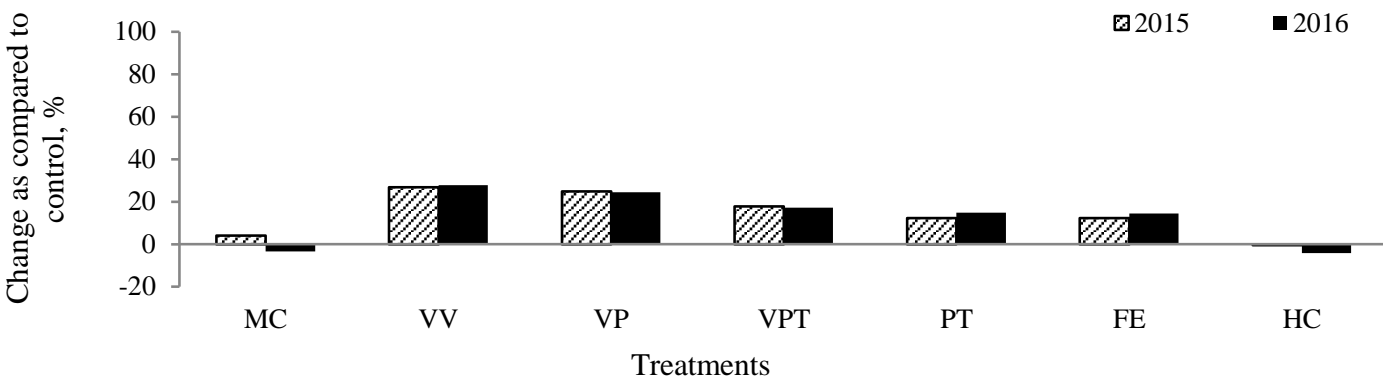

c

$\mathrm{Mn}$

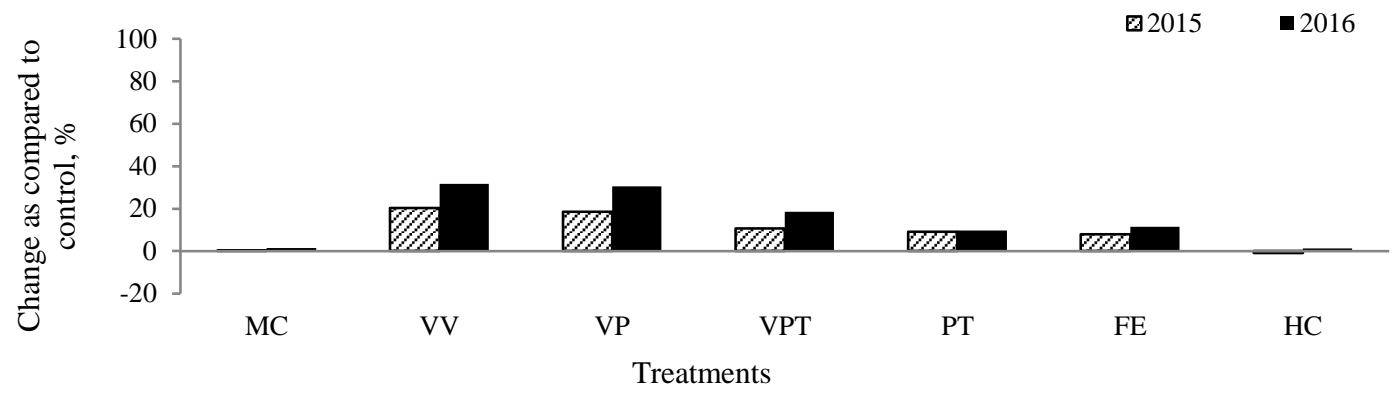

d

$\mathrm{Zn}$

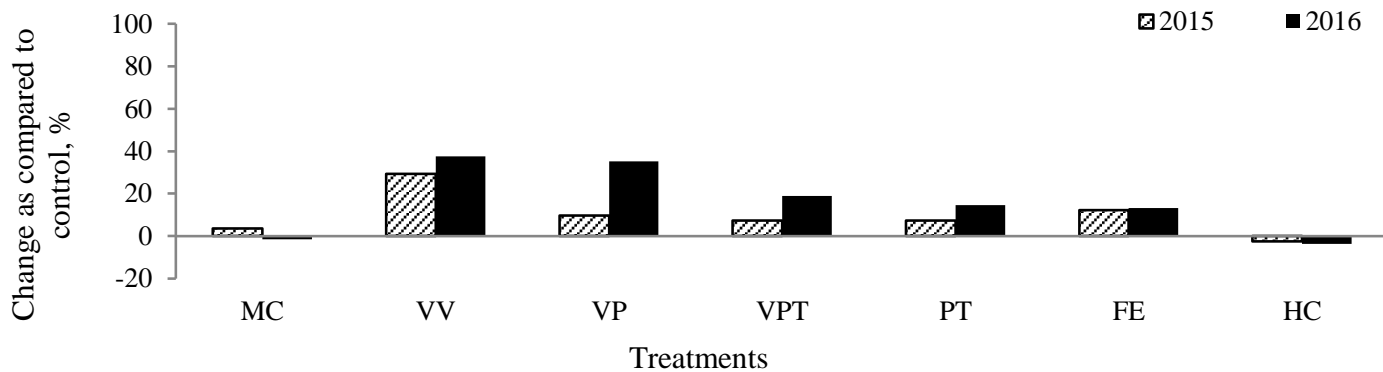

Figure 3 Changes (\%) in a) pH, b) Fe, c) Mn and d) $\mathrm{Zn}$ contents at 0-20 cm soil depth as compared to the bare control in the apricot orchard 
Extractable Zn contents of the soils generally increased with cover crops treatments according to the bare control in the apricot orchard $(\mathrm{F}=24.427, \mathrm{P}=0.000)$ (Figure $2 \mathrm{c}$ ). The highest extractable $\mathrm{Zn}$ content $\left(1.03 \mathrm{mg} \mathrm{kg}^{-1}\right)$ in the second year of the experiment (2016) was obtained in the VV treatment while the lowest extractable $\mathrm{Zn}$ content $(0.72$ $\mathrm{mg} \mathrm{kg}{ }^{-1}$ ) was in the $\mathrm{HC}$ treatment at $0-20 \mathrm{~cm}$ soil depth. Extractable $\mathrm{Zn}$ contents $\left(\mathrm{mg} \mathrm{kg}^{-1}\right)$ was ordered as; $\mathrm{HC}$ $(0.72)<\mathrm{MC}(0.73)<\mathrm{BC}(0.74)<\mathrm{FE}(0.85)<\mathrm{PT}(0.86)<$ VPT $(0.89)<$ VP $(1.01)<$ VV (1.03). As compared to bare control, percent increases in extractable $\mathrm{Zn}$ content at 0 $20 \mathrm{~cm}$ soil depth varied between $13.15 \%$ in $\mathrm{FE}$ and $37.54 \%$ in VV treatments $(\mathrm{F}=24.427, \mathrm{P}=0.000)$ (Figure $3 \mathrm{~d}$ ). Similarly, together with increasing soil acidification, a raise is founded of the content of available $\mathrm{Mn}, \mathrm{Fe}, \mathrm{Cu}$ and Zn in soil (Sienkiewicz et al., 2009; Rutkowska et al., 2009; Li et al., 2007). Organic fertilization affects the content of available these element forms in soil. $\mathrm{Zn}$ content in soil increments under the effect of organic matter, because this element forms labile organicmineral complexes (Behera et al., 2011). Correspondingly, organic matter and high soil $\mathrm{pH}$ also affect the availability and absorption of $\mathrm{Zn}$ (Hacisalihoglu and Kochiam, 2003). Other factors such as mycorrhizal fungi may effect the availability of zinc in the soil (Liu et al., 2000). In addition to this, organic manure (animal manures and green manure) can supply micronutrients to plants and may also mobilize soil metal cations by chelation and complexing with organic compounds, making them more available for plant uptake (Savithri et al., 1999). Franzluebbers and Hons (1996) also determined increases in $\mathrm{Zn}$ in soil under cover crop treatments.
Extractable $\mathrm{Cu}$ content varied between $2.96 \mathrm{mg} \mathrm{kg}^{-1}$ in $\mathrm{HC}$ and $3.46 \mathrm{mg} \mathrm{kg}^{-1}$ in VV and VP treatments $(\mathrm{F}=2.412$, $\mathrm{P}=0.066$ ) (Figure $2 \mathrm{~d}$ ). Cover crop treatments increased the extractable $\mathrm{Cu}$ contents in the soil: however, these increments were not found to be significant. Soil organic matter exerts a important and direct affect on the availability of $\mathrm{Mn}, \mathrm{Fe}$ and $\mathrm{Zn}$ but has little effect on the availability of soil $\mathrm{Cu}$ (Zhang et al., 2001). $\mathrm{Cu}$ is taken up by the plants in only very little amounts (Fageria, 2009).

The differences in the DTPA-extractable micronutrients ( $\mathrm{Fe}, \mathrm{Mn}$ and $\mathrm{Zn}$ ) and $\mathrm{pH}$ values of soils in the orchard was not found to be significant for $20-40 \mathrm{~cm}$ soil depth in both years of experiments (Table 2). Descriptive statistics for the soil properties at $20-40 \mathrm{~cm}$ soil depth were given in Table 4.

Descriptive statistics of orchard soils at $0-20 \mathrm{~cm}$ soil depth are indicated in Table 3. As indicated in this table, $\mathrm{pH}$ values of apricot orchard soils at the end of the experiment were found between 6.89-7.58\%. Mean extractable $\mathrm{Fe}, \mathrm{Zn}$ and $\mathrm{Cu}$ contents were measured as 12.93 $\mathrm{mg} \mathrm{kg}{ }^{-1}, 7.23 \mathrm{mg} \mathrm{kg}^{-1}, 0.86 \mathrm{mg} \mathrm{kg}^{-1}$ and $3.21 \mathrm{mg} \mathrm{kg}^{-1}$, respectively. Regarding available DTPA-extractable micronutrient $(\mathrm{Fe}, \mathrm{Zn}$ and $\mathrm{Cu}$ ) values, except mean $\mathrm{Mn}$ values in the orchard was above the critical levels for deficiency in the soils (Lindsay and Norvell, 1978). Relations between the DTPA-extractable micronutrients ( $\mathrm{Fe}, \mathrm{Mn}$ and $\mathrm{Zn}$ ) and soil $\mathrm{pH}$ values were statistically significant at the different important level $(\mathrm{F}=57.892, \mathrm{P}=$ $0.000 ; \mathrm{F}=59.006, \mathrm{P}=0.000 ; \mathrm{F}=24.427, \mathrm{P}=0.000 ; \mathrm{F}=$ $21.715, \mathrm{P}=0.000$, respectively). Correlations among soil $\mathrm{pH}$ and extractable micronutrients ( $\mathrm{Fe}, \mathrm{Mn}, \mathrm{Zn}, \mathrm{Cu})$ at 0 $20 \mathrm{~cm}$ soil depth were given in Table 5.

Table 2 Effects of different cover crops and others treatments on the measured variables at $20-40 \mathrm{~cm}$ soil depth

\begin{tabular}{|c|c|c|c|c|c|c|}
\hline \multirow{2}{*}{ Year } & \multirow{2}{*}{ Treatments } & \multirow{2}{*}{$\mathrm{pH}$} & Ext. Fe & Ext. Mn & Ext. Zn & Ext. $\mathrm{Cu}$ \\
\hline & & & \multicolumn{4}{|c|}{$\mathrm{mg} \mathrm{kg}^{-1}$} \\
\hline \multirow{8}{*}{2015} & $\mathrm{BC}$ & 7,40 & 11,31 & 5,07 & 0,37 & 2,29 \\
\hline & $\mathrm{MC}$ & 7,46 & 11,20 & 5,38 & 0,36 & 2,59 \\
\hline & VV & 7,41 & 11,82 & 5,50 & 0,37 & 2,93 \\
\hline & VP & 7,43 & 11,58 & 5,48 & 0,35 & 2,74 \\
\hline & VPT & 7,45 & 11,90 & 5,20 & 0,34 & 2,74 \\
\hline & PT & 7,43 & 10,79 & 5,10 & 0,35 & 2,18 \\
\hline & FE & 7,46 & 10,57 & 5,38 & 0,34 & 2,51 \\
\hline & $\mathrm{HC}$ & 7,46 & 11,83 & 5,33 & 0,34 & 2,29 \\
\hline \multirow{8}{*}{2016} & $\mathrm{BC}$ & 7,40 & 10,93 & 5,12 & 0,33 & 2,86 \\
\hline & $\mathrm{MC}$ & 7,45 & 11,62 & 5,75 & 0,39 & 2,71 \\
\hline & VV & 7,39 & 10,12 & 5,96 & 0,40 & 2,95 \\
\hline & VP & 7,41 & 11,12 & 5,66 & 0,40 & 2,70 \\
\hline & VPT & 7,51 & 10,91 & 5,21 & 0,45 & 2,72 \\
\hline & PT & 7,46 & 11,58 & 5,80 & 0,38 & 2,37 \\
\hline & $\mathrm{FE}$ & 7,43 & 10,03 & 5,35 & 0,34 & 2,95 \\
\hline & $\mathrm{HC}$ & 7,49 & 10,68 & 5,58 & 0,39 & 2,42 \\
\hline
\end{tabular}

Table 3 Descriptive statistics for the soil properties at $0-20 \mathrm{~cm}$ soil depth

\begin{tabular}{c|lccccccc}
\hline Year & \multicolumn{1}{|c}{ Soil properties } & Minimum & Maximum & Mean & Std. Dev. & CV,\% & Skewness & Kurtosis \\
\hline \multirow{3}{*}{2015} & pH & 7.09 & 7.50 & 7.29 & 0.147 & 2.02 & 0.140 & -1.597 \\
& Ext. Fe, mg kg-1 & 10.24 & 14.66 & 12.79 & 1.192 & 9.32 & -0.076 & -0.866 \\
& Ext. $\mathrm{Mn}, \mathrm{mg} \mathrm{kg}^{-1}$ & 5.60 & 8.00 & 6.74 & 0.682 & 10.12 & 0.094 & -0.793 \\
\hline \multirow{5}{*}{2016} & $\mathrm{pH}$ & 6.89 & 7.58 & 7.25 & 0.194 & 2.68 & 0.086 & -1.154 \\
& Ext. Fe, $\mathrm{mg} \mathrm{kg}^{-1}$ & 10.69 & 15.28 & 12.93 & 1.414 & 10.94 & -0.162 & -1.310 \\
& Ext. Mn, mg kg-1 & 6.00 & 8.67 & 7.23 & 0.796 & 11.01 & 0.410 & -1.103 \\
& Ext. Zn, mg kg-1 & 0.68 & 1.12 & 0.86 & 0.122 & 14.19 & 0.548 & -0.594 \\
\hline
\end{tabular}


Table 4 Descriptive statistics for the soil properties at 20-40 $\mathrm{cm}$ soil depth

\begin{tabular}{c|lccccccc}
\hline Year & \multicolumn{1}{|c}{ Soil properties } & Minimum & Maximum & Mean & Std. Dev. & CV,\% & Skewness & Kurtosis \\
\hline \multirow{5}{*}{2015} & $\mathrm{pH}$ & 7,30 & 7,54 & 7,44 & 0,05 & 0,70 & $-0,638$ & 0,615 \\
& Ext. Fe, mg kg-1 & 10,35 & 12,51 & 11,37 & 0,58 & 5,06 & 0,02 & $-0,922$ \\
& Ext. $\mathrm{Mn}, \mathrm{mg} \mathrm{kg}^{-1}$ & 4,40 & 5,80 & 5,30 & 0,35 & 6,58 & $-0,552$ & $-0,306$ \\
& Ext. Zn, mg kg-1 & 0,27 & 0,47 & 0,36 & 0,04 & 12,43 & 0,25 & 0,303 \\
& Ext.Cu, mg kg-1 & 1,80 & 3,30 & 2,53 & 0,40 & 15,98 & 0,247 & $-0,908$ \\
\hline \multirow{5}{*}{2016} & pH & 7,28 & 7,53 & 7,44 & 0,06 & 0,80 & $-0,438$ & 0,024 \\
& Ext. Fe, mg kg-1 & 9,28 & 12,86 & 10,87 & 0,89 & 8,19 & 0,448 & $-0,439$ \\
& Ext. $\mathrm{Mn}, \mathrm{mg} \mathrm{kg}^{-1}$ & 3,87 & 6,99 & 5,55 & 0,75 & 13,46 & 0,081 & $-0,483$ \\
& Ext. Zn, mg kg-1 & 0,30 & 0,51 & 0,39 & 0,06 & 14,95 & 0,539 & $-0,839$ \\
& Ext. $\mathrm{Cu}, \mathrm{mg} \mathrm{kg}^{-1}$ & 2,32 & 3,01 & 2,71 & 0,21 & 7,92 & $-0,539$ & $-0,809$ \\
\hline
\end{tabular}

Table 5 Correlations among soil $\mathrm{pH}$ and extractable micronutrients (Fe, $\mathrm{Mn}, \mathrm{Zn}, \mathrm{Cu}$ ) at 0-20 cm soil depth

\begin{tabular}{|c|c|c|c|c|c|}
\hline Soil properties & Treatments & Ext.Fe & Ext.Mn & Ext.Cu & Ext.Zn \\
\hline \multirow{7}{*}{$\mathrm{pH}$} & $\mathrm{MC}$ & 0.499 & 0.453 & 0.372 & 0.598 \\
\hline & VV & $-0.985^{* *}$ & $-0.945^{* *}$ & -0.637 & $0.764^{*}$ \\
\hline & VP & $-0.948^{* *}$ & $-0.928^{* *}$ & -0.646 & $0.722^{*}$ \\
\hline & VPT & $-0.897^{* *}$ & $-0.891^{* * *}$ & -0.645 & $0.714^{*}$ \\
\hline & $\mathrm{PT}$ & $-0.853^{* *}$ & $-0.837^{* *}$ & -0.510 & $0.703^{*}$ \\
\hline & $\mathrm{FE}$ & $-0.853^{* *}$ & $-0.806^{* *}$ & 0.548 & 0.652 \\
\hline & $\mathrm{HC}$ & -0.081 & 0.311 & 0.342 & 0.384 \\
\hline \multirow{7}{*}{ Ext. Fe } & $\mathrm{MC}$ & & 0.554 & 0.530 & 0.426 \\
\hline & VV & & $0.898^{* *}$ & $0.842^{* *}$ & $0.987^{* *}$ \\
\hline & VP & & $0.999^{* *}$ & $0.851^{* *}$ & $0.980^{* *}$ \\
\hline & VPT & & $0.998^{* *}$ & 0.689 & $0.978^{* *}$ \\
\hline & PT & & $0.985^{* *}$ & 0.687 & $0.980^{* *}$ \\
\hline & $\mathrm{FE}$ & & $0.996^{* *}$ & $0.922^{* *}$ & $0.967^{* *}$ \\
\hline & $\mathrm{HC}$ & & 0.468 & 0.344 & 0.540 \\
\hline \multirow{7}{*}{ Ext. Mn } & $\mathrm{MC}$ & & & 0.464 & 0.465 \\
\hline & VV & & & $0.829^{*}$ & $0.885^{* *}$ \\
\hline & VP & & & $0.828^{*}$ & $0.877^{* *}$ \\
\hline & VPT & & & 0.672 & $0.876^{* *}$ \\
\hline & PT & & & $0.797^{*}$ & $0.776^{* *}$ \\
\hline & $\mathrm{FE}$ & & & 0.644 & $0.775^{*}$ \\
\hline & $\mathrm{HC}$ & & & 0.347 & 0.368 \\
\hline \multirow{7}{*}{ Ext. $\mathrm{Cu}$} & $\mathrm{MC}$ & & & & 0.506 \\
\hline & VV & & & & $0.882^{* *}$ \\
\hline & VP & & & & $0.895^{* *}$ \\
\hline & VPT & & & & $0.766^{*}$ \\
\hline & PT & & & & $0.729^{*}$ \\
\hline & $\mathrm{FE}$ & & & & $0.774^{*}$ \\
\hline & $\mathrm{HC}$ & & & & 0.415 \\
\hline
\end{tabular}

Mechanically cultivated (MC), Vicia villosa Roth (VV), Vicia pannonica Crantz (VP), Vicia pannonica Crantz and Tritikale mixture $(70 \%+30 \%$, respectively) (VPT), Phacelia tanacetifolia Benth (PT), Fagopyrum esculentum Moench (FE), herbicide treatment (HC)

Table 6 Statistical results for the independent two samples t-test analysis between the 2015 and 2016 years

\begin{tabular}{|c|c|c|c|c|c|c|c|}
\hline Soil properties & Years & $\mathrm{N}$ & Mean & Std. Deviation & Mean Std. Error & $\mathrm{F}$ & Sig. \\
\hline \multirow{2}{*}{$\mathrm{pH}$} & 2015 & 32 & 7,29 & 0,147 & 0,026 & \multirow{2}{*}{3,396} & \multirow{2}{*}{0,070} \\
\hline & 2016 & 32 & 7,25 & 0,194 & 0,034 & & \\
\hline \multirow{2}{*}{ Ext. Fe } & 2015 & 32 & 12,79 & 1,192 & 0,211 & \multirow{2}{*}{2,155} & \multirow{2}{*}{0,147} \\
\hline & 2016 & 32 & 12,93 & 1,414 & 0,250 & & \\
\hline \multirow{2}{*}{ Ext. Mn } & 2015 & 32 & 6,74 & 0,682 & 0,121 & \multirow{2}{*}{1,322} & \multirow{2}{*}{0,255} \\
\hline & 2016 & 32 & 7,23 & 0,796 & 0,141 & & \\
\hline \multirow{2}{*}{ Ext. Zn } & 2015 & 32 & 0,89 & 0,147 & 0,026 & \multirow{2}{*}{0,380} & \multirow{2}{*}{0,540} \\
\hline & 2016 & 32 & 0,86 & 0,122 & 0,022 & & \\
\hline \multirow{2}{*}{ Ext. $\mathrm{Cu}$} & 2015 & 32 & 3,09 & 0,342 & 0,060 & \multirow{2}{*}{6,369} & \multirow{2}{*}{0,014} \\
\hline & 2016 & 32 & 3,21 & 0,226 & 0,040 & & \\
\hline
\end{tabular}


Significant negative correlations in the VV treatment were observed between soil $\mathrm{pH}$ and $\mathrm{Fe}\left(-0.985^{* *}\right)$, between soil $\mathrm{pH}$ and $\mathrm{Mn}\left(-0.945^{* *}\right)$, between soil $\mathrm{pH}$ and $\mathrm{Zn}(-$ $\left.0.764^{*}\right)$ in the orchard. Significant negative correlations in the VP treatment were observed between soil $\mathrm{pH}$ and $\mathrm{Fe}(-$ $\left.0.948^{* *}\right)$, between soil $\mathrm{pH}$ and $\mathrm{Mn}\left(-0.928^{* *}\right)$, between soil $\mathrm{pH}$ and $\mathrm{Zn}(-0.722 *)$ in the orchard. Statistical results for the independent two samples t-test analysis between the 2015 and 2016 years were given in Table 6. The results of this study are accordance with those of the studies mentioned above. Similar findings about relationship between available micronutrients and $\mathrm{pH}$ of soil were determined by Kumar and Babel (2011) and Demir and Gülser (2010). The various researcher Sharma et al. (2003), Mathur et al. (2006), Yadav and Meena (2009) and Sidhu and Sharma (2010) identified important and negative correlation between soil $\mathrm{pH}$ and available Fe, $\mathrm{Mn}, \mathrm{Zn}$.

\section{Conclusion}

This study showed that cover crop treatments generally increased DTPA-extractable micronutrients (Fe, Mn and $\mathrm{Zn}$ ) at $0-20 \mathrm{~cm}$ soil depth in the apricot orchard with clay texture soil. While the DTPA-extractable micronutrients (Fe, $\mathrm{Mn}$ and $\mathrm{Zn}$ ) increased, soil $\mathrm{pH}$ decreased with cover crop treatments. These nutrient (Fe, Mn and $\mathrm{Zn}$ ) contents varied from cover crop to cover crop. In both years of the experiment, there were not any significant differences in measured variables at $0-20 \mathrm{~cm}$ soil depths of a plot mechanically cultivated, herbicide treatment and bare control. Soil $\mathrm{pH}$ has generally significant negative correlations with the DTPA-extractable micronutrients. The greatest positive effects of cover crop treatments were observed in VV and VP treatments. It was concluded based on current findings that cover crops, especially Vicia villosa Roth and Vicia pannonica Crantz treatments could be incorporated into cropping systems to improve micronutrients and to provide a sustainable soil management.

\section{Acknowledgements}

Authors thank to Scientific and Technological Research Council of Turkey (TUBITAK) for financial assistance (with the project $213 \mathrm{O}$ 109) provided to the present research.

\section{References}

Ayele T, Tanto T, Ayana M. 2013. Rating and correlating physicochemical properties of Eutricvertisols in Abaya Chamo lake basin, South-west Ethiopia. Int. J Agron Plant Prod. 4: 3559-3568.

Barber SA. 1995. Soil Nutrient Bioavailability. A Mechanistic Approach, 2nd ed. John Wiley and Sons, New York, USA.

Behera SK, Singh MV, Singh KN, Todwal S. 2011. Distribution variability of total extractable zinc in cultivated acid soils of India and their relationship with some selected soil properties. Geoderma, 162: 242-250.

Bernardi ACC, Machado PLOA, Freitas PL, Coelho MR, Leandro WM, Oliveira Júnior JP, Oliveira RP, Santos HG, Madari BE, Carvalho MCS. 2003. Soil liming and fertilization in the no tillage system at Cerrado. Rio de Janeiro, Embrapa Solos. 22p.
Brady NC, Weil RR. 1999. The nature and properties of soils, 12th Edition. Prentice Hail, Upper Saddle River, New Jersey.

Brady NC, Weil RR. 2002. Weil, The nature and properties of soils. 13th edition, Pearson Education, New Jersey.

Brady NC, Weil RR. 2014. The Nature and Properties of Soil (14th ed.). Pearson Education Limited, USA.

Carvalho AM, Souza LLP, Guımarães Júnıror R, Alves PCAC, Vivald1 LJ. 2011. Cover plants with potential use for crop-livestock integrated systems in the Cerrado region. Pesquisa Agropecuária Brasileira, 46: 1200-1205.

Demir Z, Gülser C. 2010. Effects of Surface Application of Hazelnut Husk on DTPA Extractable Micro Element Contents Along a Soil Depth. International Conference on Soil Fertility and Soil Productivity, Differences of Efficiency of Soils for Land Uses, Expenditures and Returns. 17-20 March, Humboldt-University Berlin, Germany. (Abstract), 3 / 2010

Demir Z, Tursun N, Işık D. 2019. Effects of different cover crops on soil quality parameters and yield in an apricot orchard. Intl. J. Agric. Biol., 21: 399-408.

Demiralay I. 1993. Soil physical analysis. Ataturk Univ. Agric. Fac. Pub. No: 143, Erzurum, Turkey.

Fabian A. 2009. Cover crops: effects in the soil attributes and in the productivity of corn and soybean in rotation schemes. Doctoral thesis. Universidade estadual Paulista, Jaboticabal. 99p.

Fageria NK. 2002. Influence of micronutrients on dry matter yield and interaction with other nutrients in annual crops. Pesquisa. Agropecuaria Brasileira, 37: 1765-1772.

Fageria NK. 2009. The use of nutrients in crop plants. Boca Raton.

Fageria NK, Ferreira EPDB, Knupp AM. 2015. Micronutrients use efficiency in tropical cover crops as influenced by phosphorus fertilization. Revista Caatinga, Mossoró, 28(1):130-137.

Franzluebbers AJ, Hons FM. 1996. Soil - profile distribution of primary and secondary plant-avaliable nutrients under conventional and no tillage. Soil Tillage Research, 39: 229239.

Garcia RA, Rosolem CA. 2010. Aggregates in a Rhodic Ferralsol under no-tillage and crop rotation. Pesquisa Agropecuária Brasileira, 45: 1489-1498.

Hacisalihoglu G, Kochiam LV. 2003. How do some plants tolerate low levels of soil zinc? Mechanisms of zinc efficiency in crop plants. New Phyt., 159: 341-350.

Ibrahim S, Faryal S. 2014. Augmentation of Trigonella foenumgraecum L. (methi) Growth under Salinity Stress and Allelochemical stress Through $\mathrm{Mn}^{+} \mathrm{B}^{+} \mathrm{Zn}$ Mixture Foliar Spray. Journal of Phar-macognosy and Phytochemistry, 3 (2): $39-44$.

Ju XT, Kou CL, Zhang FS, Christie P. 2006. Nitrogen balance and groundwater nitrate contamination: Comparison among three intensive cropping systems on the North China Plain. Environ. Pollut., 143: 117-125.

Kacar B. 1994. Chemical Analysis of Plant and Soil-III. Soil Analysis, 705. Ankara University Faculty of Agriculture, Ankara, Turkey. No. 3.

Lal R. 2009. Soil and food sufficiency: A review. Agron Sutain. Dev., 29: 113-133.

Landon JR. 1984. Tropical Soil Manual. Booker Agriculture. International Limited, Londres. 450pp.

Li BY, Zhou DM, Cang L, Zhang HL, Fan XH, Qin SW. 2007. Soil micronutrient availability to crops as affected by longterm inorganic and organic fertilizer applications. Soil and Tillage Research, 96: 166-173.

Li PJ, Wang X, Allinson G, Li XJ, Xiong XZ. 2009. Risk assessment of heavy metals in soil previously irrigated with industrial wastewater in Shenyang, China. Journal of Hazardous Materials. 161(1): 516-521. 
Loneragan J, Webb MJ. 1993. Interactions between zinc and other nutrients affecting the growth plants. Zinc in soils and plants, Robson, A. D. (eds.), Soil Science and Plant Nutrition, School of Agriculture. The University of Western Australia, Perth, 119-132pp.

Marschner P, Rengel Z. 2007. Nutrient Cycling in Terrestrial Ecosystems. Springer Science \& Business Media. Berlin, Heidelberg.

Mathur GM, Deo R, Yadav BS. 2006. Status of zinc in irrigated north-west plain soils of Rajasthan. J. Indian Soc. Soil Sci., 54(3): 359-361.

Moreti D, Alves MC, Valerio Filho WV, Carvalho MP. 2007. Soil chemical attributes of a red latosol under different systems of preparation, management, and covering plants. Revista Brasileira de Ciência do Solo, 31: 167-175.

Nascente AS, Crusciol CAC, Cobucci T. 2013. The no-tillage system and cover crops-Alternatives to increase upland rice yield. European Journal of Agronomy, 45: 124-131.

Pacheco LP, Leandro WM, Machado PLOA, Assis RL, Cobucci T, Madari BE, Petter FA. 2011. Biomass production and nutrient accumulation and release by cover crops in the offseason. Pesquisa Agropecuária Brasileira, 46: 17-25.

Rutkowska B, Szulc W, Labętowicz J. 2009. Influence of soil fertilization on concentration of microelements in soil solution of sandy soil. Journal of Elementology, 14: 349-355.

Savithri P, Perumal R, Nagarajan R. 1999. Soil and crop management technologies for enhancing rice production under micronutrient constraints. Nutr. Cycling Agroecosystems, 53: 81-92.

Sharma RP, Singh M, Sharma JP. 2003. Correlation studies onmicronutrients vis-à-vis soil properties in some soils of Nagaur district in semi-arid region of Rajasthan. J. Indian Soc. Soil Sci., 51(4): 522-527.
Sidhu GS, Sharma BD. 2010. Diethylenetriaminepentaacetic Acid-Extractable Micronutrients Status in Soil under a RiceWheat System and Their Relationship with Soil Properties in Different Agro-climatic Zones of Indo-Gangetic Plains of India, Communications in Soil Science and Plant Analysis, 41(1): $29-51$.

Sienkiewicz S, Wojnowska T, Krzebietke S, Wierzbowska J, Żarczyński P. 2009. Content of available forms of some micronutrients in soil after long-term differentiated fertilization. Journal of Elementology, 14: 787-794.

Singh SK. 2012. Annual Report, Preparation of GPS and GIS based soil fertility map of the selected district of the country, funded by IISS (ICAR), Bhopal and MOA, New Delhi.

Soil Survey Staff. 1993. Soil survey manuel.USDA Handbook. No: 18, Washington D.C.

Wang Y, Zhang X, Huang C. 2009. Spatial variability of soil total nitrogen and soil total phosphorus under different land uses in a small watershed on the Loess Plateau, China. Geoderma. 150: 141- 149.

White PJ, Broadley MR. 2009. Biofortification of crops with seven mineral elements often lacking in human diets: iron, zinc, copper, calcium, magnesium, selenium and iodine. New Phytol. 182: 49-84.

Yadav BK. 2011. Micronutrient Status of Soils under Legume Crops in Arid Region of Western Rajasthan, India Sciences, 4: 94-97.

Yadav RL, Meena MC. 2009. Available micronutrients status and relationship with soil properties of Degana soil series of Rajasthan. J. Indian Soc. Soil Sci., 57(1): 90-92.

Ying GG. 2006. Fate, behavior and effects of surfactants and their degradation products in the environment. Environ Int. 32: 417-431.

Yurtsever N. 1984. Experimental statistical methods. T.C. Ministry of Agriculture and Forestry, Pub. No: 121.

Zhang SX, Wang XB, Jin K. 2001. Effect of different N and P levels on availability of zinc, copper, manganese and iron under arid conditions. Plant Nutr. Fert. Sci. (7):391-396. 